Case Report

\title{
A Rare Cause of a Scrotal Abscess due to the Symbiotic Infection of Gardnerella vaginalis and Prevotella bivia in an Adult Male
}

\author{
Anthony Bekasiak 1,2 ${ }^{\mathbb{D}}$, Fabian Dammann ${ }^{1,2}$ and Claudia Nader 2,3,* \\ 1 Department of Medicine, St. Elizabeth's Medical Center, Boston, MA 02135, USA; \\ anthony.bekasiak@steward.org (A.B.); fabian.dammann@steward.org (F.D.) \\ 2 Tufts University School of Medicine, Boston, MA 02111, USA \\ 3 Division of Infectious Disease, St. Elizabeth's Medical Center, Boston, MA 02135, USA \\ * Correspondence: claudia.nader@steward.org
}

Received: 6 January 2020; Accepted: 30 January 2020; Published: 1 February 2020

\begin{abstract}
Gardnerella vaginalis (G. vaginalis) is the major bacteria detected in women with bacterial vaginosis (BV). Prevotella bivia (P. bivia) has been demonstrated to show a symbiotic relationship with $G$. vaginalis. Some men have been shown to be colonized with $G$. vaginalis in their urogenital or anorectal tracts, however genitourinary infections in males, including balanitis and urethritis, due to this organism appear to be much less common. In this report, we summarize previous cases of men with $G$. vaginalis infection, and we present a rare and unusual case of a unilateral scrotal abscess caused by G. vaginalis in co-infection with P. bivia.
\end{abstract}

Keywords: Gardnerella vaginalis; bacterial vaginosis; Prevotella bivia; scrotal abscess; sexually transmitted infections; male genitourinary infection

\section{Introduction}

A 27-year-old male with medical history significant only for morbid obesity with a Body Mass Index (BMI) of 43.9 presented to the emergency room with a three-day history of worsening right scrotal swelling and pain. The pain was non-radiating, dull, and severe in nature. He endorsed subjective fevers and chills, but had no urinary symptoms such as dysuria, hematuria, or frequency. He denied any trauma to the urogenital region. The patient was heterosexual with history of two sexual partners, with his most recent sexual encounter three months prior to his presentation during which a condom was used for barrier precaution. He did not know whether the sexual partner had bacterial vaginosis (BV) or was colonized with these bacteria. He denied any prior history of sexually transmitted infections or Human Immunodeficiency Virus (HIV).

Upon presentation, he was afebrile with stable vital signs. Genitourinary examination revealed a circumcised penis without any lesions or discharge or evidence of phimosis. The scrotum on the right side appeared erythematous, swollen, and tender, suggestive of a cellulitis, with a large fluctuant palpable mass, but no signs of induration. Blood work was pertinent for a White Blood Cell (WBC) count of $16.1 \times 10.3 / \mu \mathrm{L}$, with $77 \%$ neutrophils with left shift. Urinalysis showed $<1$ high-power field (HPF) WBCs with negative leukocyte esterase and nitrite. Urine nucleic acid amplification test (NAAT) was negative for the presence of pathogen DNA of trichomonas, gonorrhea, and chlamydia. A scrotal ultrasound revealed normal echotexture in both testes without focal abnormalities and no evidence of hydroceles or varicoceles. Arterial and venous outflow was normal. Marked thickening of the skin of the scrotum was noted with echogenic inflamed fat with hyperemia more noticeable on the right. An echogenic collection seen adjacent to the right hemiscrotum with a deeper component measuring up to $4.9 \times 2 \mathrm{~cm}$ was visualized. A Computed Tomography (CT) of the pelvis with intravenous (IV) 
contrast was subsequently obtained, which did not reveal any radiographic feature suggestive of Fournier's gangrene. He was initiated empirically on IV ceftriaxone $1 \mathrm{~g}$ daily. He underwent a bedside incision and drainage of the abscess. Purulent material was noted and was sent to microbiology.

Gram stain revealed many polymorphonuclear cells, few Gram-positive cocci in pairs, and scarce Gram-negative rods. The abscess specimen was plated on sheep blood agar, chocolate agar, and MacConkey agar for aerobic incubation, and was incubated at $37{ }^{\circ} \mathrm{C}$ in $5 \%$ carbon dioxide. The specimen was also plated on an anaerobic blood agar enriched with vitamin $\mathrm{K}$, an anaerobic phenylethyl alcohol agar, and in thioglycollate broth for anaerobic culture, and incubated at $37^{\circ} \mathrm{C}$ in an anaerobic atmosphere. After 72 hours of incubation, small dry colonies with alpha-hemolysis were observed on both the sheep blood and chocolate agars. Catalase test was negative. VITEK 2 system (BioMérieux, Cambridge, MA, USA) was used for rapid bacterial identification, and the organism was identified as Gardnerella vaginalis with the VITEK 2 GP ID card. Anaerobic growth was noted after 3 days in broth only. VITEK 2 system (BioMérieux) identified the organism as Prevotella bivia with the VITEK 2 ANC ID card. Fungal cultures were negative. The patient had clinical response to the empiric ceftriaxone initiated at presentation, and his WBC down trended to normal range. He was discharged home on cephalexin $500 \mathrm{mg}$ p.o. four times a day, and metronidazole $500 \mathrm{mg}$ three times a day for a total of fourteen days, with instruction to follow up with his primary care physician in one week for repeat scrotal ultrasound and at the wound center to ensure proper wound care and appropriate wound healing. Regrettably, the patient had personal commitments obliging him to leave the state, thus, he was lost for any clinical follow-up. Fortunately, his contact information remained the same, and he was telephoned two months later, with the patient reporting complete resolution of his symptoms.

\section{Discussion}

G. vaginalis is typically associated with BV in women, which is the most common cause of vaginal discharge [1]. BV is characterized by loss of lactic acid-producing Lactobacillus spp. that compose the normal vaginal flora, with an increase in facultative and strict anaerobic bacteria, including G. vaginalis, Prevotella spp., Atopobium vaginae, Sneathia spp., and other bacterial vaginosis-associated bacteria (BVAB). Recent findings by Muzny et al. show that despite the high abundance of G. vaginalis and P. bivia in women with $\mathrm{BV}$, neither induced a robust inflammatory response from vaginal epithelial cells, suggesting that these pathogens are early colonizers evading the immune system while establishing the BV biofilm. As a result, secondary colonizers, including A. vaginae, Sneathia spp., and other BVAB, act as more potent stimulators of the hos-immune response to $\mathrm{BV}$, leading to the signs, symptoms, and its adverse effects [2]. The treatment of BV in symptomatic women has been established with metronidazole or clindamycin. G. vaginalis has been reported to cause complications following delivery or pelvic surgery, such as preterm rupture of membranes, chorioamnionitis, and postpartum fever [3-5]. Disease due to $G$. vaginalis in men has been reported but is very uncommon.

\subsection{Sexual Transmission of Gardnerella vaginalis}

In 1953, an organism presumed to be G. vaginalis was isolated by Leopold from cultures of urethral swabs and urine specimens from men suffering from urethritis or prostatitis [6]. In 1955, G. vaginalis was then further studied by Gardner and Dukes, who found that Gardnerella was isolated from the urethras of $86 \%$ of husbands of women with BV [7]. In 1984, Piot et al. worked on biotyping G. vaginalis and found that biotypes isolated from vaginal cultures of women with BV and from the urethras of their sexual partners were identical more than $90 \%$ of the time when sampled within 24 hours; this study further demonstrates the fact that G. vaginalis can be sexually transmitted [8]. In the past, it was reported that up to $7 \%-11 \%$ of men had G. vaginalis as part of their urogenital or anorectal flora, leading to the possibility of urinary tract colonization and infection [9]. In a cohort study in Sweden of male attendees of a sexually transmitted infection (STI) clinic, urethral carriage of $G$. vaginalis was noted to be $4.5 \%$ (10 out of 309) [10]. In uncircumcised men, G. vaginalis more 
frequently colonizes, and is easier to isolate from the glans penis and prepuce than from the urethra, where the organism can easily be eradicated by micturition [11]. Moreover, semen or the prostate gland appear to be possible reservoirs for G. vaginalis. A report of an otherwise healthy male with no clinical features to suggest infection presented to an STI clinic, as his female sexual partner had recurring BV infections despite metronidazole treatment. His semen was analyzed, yielding a growth of $G$. vaginalis, and both partners received metronidazole, with resolution of the female's recurrent BV [12]. In a study by Lam et al., G. vaginalis was recovered from 4 out of 12 semen samples, as well 4 out of 7 urethral samples [13]. Semen specimen growth of G. vaginalis was also noted in three infertility clinics. One clinic noted that $19 \%$ of isolated microorganisms from 36 semen samples were identified as G. vaginalis [14]. The second clinic isolated 552 microorganisms from 182 males, 52 out of which were G. vaginalis (9.6\%) [15]. In addition, when semen samples were obtained with at least 3 days of sexual abstinence, 22 out of 38 semen samples (58\%) isolated G. vaginalis, raising the possibility of male colonization. There was no association between the isolation of G. vaginalis and the sperm count [16].

Heterosexual contact, as in female-to-male transmission, appears to enhance male carriage of G. vaginalis, as documented by Holst. BV-associated organisms (Mobiluncus mulieris, M. curtisii, and G. vaginalis) were isolated in this study from male consorts of women with BV, then after two weeks of consistent condom use, the isolates of the BV-associated organisms disappeared [17]. Similarly, in a later study suggestive for female-to-male transmission, G. vaginalis carriage by men was closely linked to lack of condom use [18]. Sexual behavior-related characteristics have also been associated with BV. These include young age at coitarche, life-time number of sex partners, recent history of multiple sex partners, and a recent history of a new sex partner. However, what classifies these factors as high-risk sexual behavior that can lead to BV infections appears inconsistent [19].

\subsection{Gardnerella vaginalis Male Infections}

A review of the literature performed via PubMed database using the Medical Subject Headings (MeSH) of "Gardnerella vaginalis" and "male" identified 21 cases of G. vaginalis adult male infections published in individual case reports and case series (Table 1). In brief, patients presented with ages between 19 and 78 years, with an average age of 47 years.

While balanitis is usually caused by Candida organisms, anaerobes with mixed species, including G. vaginalis, were found to be the culprit in some cases [20]. Bacteremia due to G. vaginalis has been reported in men with immunosuppression, chronic alcohol use disorder, urethral stenting, meatal strictures, infected urinoma, prostate adenomas, or transurethral prostatectomy [21-30]. In two otherwise healthy patients, G. vaginalis bacteremia was found in a male presenting only with urethritis, raising the question of whether G. vaginalis is overlooked, and another with only a positive urine culture [31,32]. Other males with no significant medical histories were found with either urolithiasis or nephrolithiasis leading to pyelonephritis and G. vaginalis bacteremia [33,34]. Though limited in detail, a male with an indwelling catheter for over six hours was reported to develop G. vaginalis infection [30]. Lastly, another healthy male was found with pyelonephritis associated with G. vaginalis septicemia complicated by infective endocarditis and septic emboli to the kidney and brain [35]. Of note, 7 of the 21 cases note some element of prostatic disease, supporting the hypothesis of the prostate as a possible reservoir for G. vaginalis $[21,25,27,29-31]$. 
Table 1. Reported cases of G. vaginalis infections in male patients.

\begin{tabular}{|c|c|c|c|c|c|}
\hline Year & $\begin{array}{l}\text { Corresponding Author } \\
\text { and Journal [Reference] }\end{array}$ & Case Description & Culture Site & Culture Results & $\begin{array}{l}\text { Antibiotic Therapy Duration in Days } \\
\text { (If Reported) }\end{array}$ \\
\hline 1978 & $\begin{array}{l}\text { Abercrombie } \\
\text { Lancet [32] }\end{array}$ & $\begin{array}{l}\text { 20-year-old healthy male developed } \\
\text { UTI. }\end{array}$ & Urine & G. vaginalis & Doxycycline (n/a) \\
\hline 1978 & $\begin{array}{c}\text { Patrick } \\
\text { Lancet [27] }\end{array}$ & $\begin{array}{l}\text { 57-year-old male developed G. vaginalis } \\
\text { bacteremia following TURP. }\end{array}$ & Blood & G. vaginalis & TMP-SMX (n/a) \\
\hline 1981 & $\begin{array}{c}\text { Finkelhor } \\
\text { New England Journal of } \\
\text { Medicine [26] }\end{array}$ & $\begin{array}{l}\text { 37-year-old male with renal transplant } \\
\text { (on azathioprine and prednisone) } \\
\text { developed ascending G. vaginalis UTI } \\
\text { and perinephric abscess. }\end{array}$ & $\begin{array}{l}\text { I. Urine II. Perinephric } \\
\text { abscess }\end{array}$ & $\begin{array}{l}\text { I. G. vaginalis II. } \\
\text { S. epidermidis and } \\
\text { Enterobacter sp. }\end{array}$ & Doxycycline (n/a) \\
\hline 1986 & $\begin{array}{c}\text { Burdge } \\
\text { Sexually Transmitted } \\
\text { Diseases [20] }\end{array}$ & $\begin{array}{l}\text { 29-year-old male with gonorrhea } \\
\text { treated } 2 \text { years prior developed } \\
\text { urethral discharge, erythema of glans } \\
\text { penis, odor, and slight dysuria of } \\
\text { 6-month duration. }\end{array}$ & Urethra & $\begin{array}{l}\text { G. vaginalis, Viridans } \\
\text { streptococci, and } S . \\
\text { epidermidis }\end{array}$ & Metronidazole 500 mg BID (7 days) \\
\hline 1986 & $\begin{array}{c}\text { Burdge } \\
\text { Sexually Transmitted } \\
\text { Diseases [20] }\end{array}$ & $\begin{array}{l}\text { 31-year old healthy male developed } \\
\text { urethral discharge, pruritis of prepuce, } \\
\text { erythema of glans penis, and odor of } \\
\text { 9-month duration. Multiple } \\
\text { recurrences and treatments } \\
\text { followed suit. }\end{array}$ & Urethra & G. vaginalis & $\begin{array}{l}\text { I. Metronidazole } 2 \text { g p.o. once and } \\
\text { tetracycline } 500 \mathrm{mg} \text { QID (7 days) } \\
\text { II. Erythromycin } 500 \mathrm{mg} \text { QID (14 days) } \\
\text { III. Metronidazole (wife treated as well) } \\
\text { ( } 7 \text { days) } \\
\text { IV. Erythromycin } 500 \mathrm{mg} \text { QID (two } \\
\text { 14-day courses) } \\
\text { V. Clindamycin } 450 \mathrm{mg} \text { TID (10 days) }\end{array}$ \\
\hline 1986 & $\begin{array}{c}\text { Burdge } \\
\text { Sexually Transmitted } \\
\text { Diseases [20] }\end{array}$ & $\begin{array}{l}\text { 42-year-old male with gonorrhea } \\
\text { treated } 7 \text { and } 12 \text { years prior developed } \\
\text { 3-year history of intermittent urethral } \\
\text { discharge with odor. }\end{array}$ & Urethra & G. vaginalis & $\begin{array}{l}\text { I. Metronidazole } 500 \mathrm{mg} \text { BID (7 days) } \\
\text { (wife treated also) } \\
\text { II. Clindamycin } 450 \mathrm{mg} \text { TID (two } \\
\text { 10-day courses) }\end{array}$ \\
\hline 1986 & $\begin{array}{c}\text { Wilson } \\
\text { British Medical Journal [24] }\end{array}$ & $\begin{array}{l}\text { 19-year-old male with meatal stricture } \\
\text { attributed to childhood circumcision } \\
\text { developed dysuria and frequency with } \\
\text { G. vaginalis septicemia. }\end{array}$ & Blood, urine & G. vaginalis & $(\mathrm{n} / \mathrm{a})$ \\
\hline
\end{tabular}


Table 1. Cont

\begin{tabular}{|c|c|c|c|c|c|}
\hline Year & $\begin{array}{l}\text { Corresponding Author } \\
\text { and Journal [Reference] }\end{array}$ & Case Description & Culture Site & Culture Results & $\begin{array}{l}\text { Antibiotic Therapy Duration in Days } \\
\text { (If Reported) }\end{array}$ \\
\hline 1987 & $\begin{array}{c}\text { Harper } \\
\text { Journal of Clinical Pathology } \\
\text { [29] }\end{array}$ & $\begin{array}{l}\text { 60-year-old male developed G. vaginalis } \\
\text { septicemia following TURP. }\end{array}$ & Blood, urine & G. vaginalis & Gentamicin (n/a) \\
\hline 1989 & $\begin{array}{c}\text { Sturm } \\
\text { Journal of Infection [30] }\end{array}$ & $\begin{array}{l}\text { 53-year-old male developed infected } \\
\text { urinoma due to G. vaginalis. }\end{array}$ & Urine & G. vaginalis & $\begin{array}{l}\text { Amoxicillin and metronidazole (n/a) } \\
\text { Underwent right-sided nephrectomy }\end{array}$ \\
\hline 1989 & $\begin{array}{c}\text { Sturm } \\
\text { Journal of Infection [30] }\end{array}$ & $\begin{array}{l}\text { 67-year-old male presented with } \\
\text { prostatitis. }\end{array}$ & Urine & G. vaginalis & $(\mathrm{n} / \mathrm{a})$ \\
\hline 1989 & $\begin{array}{c}\text { Sturm } \\
\text { Journal of Infection [30] }\end{array}$ & 61-year-old male noted with prostatitis. & Urine & G. vaginalis & $(\mathrm{n} / \mathrm{a})$ \\
\hline 1989 & $\begin{array}{c}\text { Sturm } \\
\text { Journal of Infection [30] }\end{array}$ & $\begin{array}{l}\text { 72-year-old male developed cystitis } \\
\text { after indwelling catheter of }+6 \text {-hour } \\
\text { duration }\end{array}$ & Urine & G. vaginalis & $(\mathrm{n} / \mathrm{a})$ \\
\hline 1989 & $\begin{array}{l}\text { Legrand } \\
\text { Journal of Clinical } \\
\text { Microbiology [23] }\end{array}$ & $\begin{array}{l}\text { 41-year-old male with chronic alcohol } \\
\text { use disorder developed G. vaginalis } \\
\text { bacteremia and pulmonary abscess. }\end{array}$ & $\begin{array}{l}\text { I. Sputum } \\
\text { II. Blood } \\
\text { III. Pleural fluid }\end{array}$ & $\begin{array}{l}\text { I. Non-hemolytic } \\
\text { Streptococci and } \\
\text { Corynebacterium-like } \\
\text { organisms (reported as } \\
\text { contaminated flora) } \\
\text { II. G. vaginalis (from } \\
\text { second lot) and Strep. } \\
\text { milleri (from third lot) } \\
\text { III. Bacteroides oralis, } \\
\text { Peptostrep. sp., } \\
\text { Peptococcus sp., } \\
\text { Veillonella sp., H. } \\
\text { parainfluenzae, Strep. } \\
\text { milleri }\end{array}$ & $\begin{array}{c}\text { Ceftazidime, penicillin, minocycline, } \\
\text { metronidazole, clindamycin and } \\
\text { ampicillin; chloramphenicol injection } \\
\text { into the pleural space } \\
\text { (19 days) } \\
\text { (deceased during hospital course) }\end{array}$ \\
\hline 1990 & $\begin{array}{c}\text { Denoyel } \\
\text { Journal of Infectious } \\
\text { Disease [25] }\end{array}$ & $\begin{array}{l}\text { 65-year-old male with prostate } \\
\text { adenoma developed G. vaginalis } \\
\text { bacteremia. }\end{array}$ & Blood & G. vaginalis & Gentamicin and amoxicillin (n/a) \\
\hline
\end{tabular}


Table 1. Cont.

\begin{tabular}{|c|c|c|c|c|c|}
\hline Year & $\begin{array}{l}\text { Corresponding Author } \\
\text { and Journal [Reference] }\end{array}$ & Case Description & Culture Site & Culture Results & $\begin{array}{l}\text { Antibiotic Therapy Duration in Days } \\
\text { (If Reported) }\end{array}$ \\
\hline 1997 & $\begin{array}{c}\text { Bastida } \\
\text { European Journal of Clinical } \\
\text { Microbiology \& Infectious } \\
\text { Disease [21] }\end{array}$ & $\begin{array}{l}\text { 78-year-old male with history of lung } \\
\text { resection for lung malignancy, chronic } \\
\text { alcohol use disorder, chronic prostatic } \\
\text { symptoms, and recurrent UTI } \\
\text { developed G. vaginalis bacteremia. }\end{array}$ & Blood & G. vaginalis & $\begin{array}{l}\text { Cefonicid IV } \\
\text { (10 days) }\end{array}$ \\
\hline 2005 & $\begin{array}{c}\text { Calvert } \\
\text { Journal of Infectious Disease } \\
{[22]}\end{array}$ & $\begin{array}{l}\text { 50-year-old male with chronic alcohol } \\
\text { use disorder and tobacco dependency } \\
\text { developed G. vaginalis sepsis with } \\
\text { perinephric abscess and empyema. }\end{array}$ & $\begin{array}{l}\text { Blood, perinephric } \\
\text { abscess, pleural fluid }\end{array}$ & G. vaginalis & $\begin{array}{l}\text { Benzylpenicillin, cefuroxime, and } \\
\text { metronidazole; discharged on oral } \\
\text { metronidazole and amoxicillin } \\
\text { (79 days total) }\end{array}$ \\
\hline 2008 & $\begin{array}{c}\text { Lagace } \\
\text { Journal of Clinical } \\
\text { Microbiology [33] }\end{array}$ & $\begin{array}{l}\text { 41-year-old healthy male developed } G \text {. } \\
\text { vaginalis bacteremia. }\end{array}$ & Blood & G. vaginalis & $\begin{array}{l}\text { Ciprofloxacin IV } \\
\text { (10 days) }\end{array}$ \\
\hline 2010 & $\begin{array}{c}\text { Yoon } \\
\text { International Journal of STD } \\
\mathcal{E} \text { AIDS [35] }\end{array}$ & $\begin{array}{l}\text { 39-year old male with diabetes mellitus } \\
\text { developed G. vaginalis septicemia with } \\
\text { pyelonephritis, infective endocarditis, } \\
\text { and septic emboli in the kidney } \\
\text { and brain. }\end{array}$ & Blood & G. vaginalis & $\begin{array}{l}\text { IV metronidazole, ceftriaxone, and oral } \\
\text { erythromycin, } \\
\text { discharged on p.o. metronidazole ( } 96 \\
\text { days); then aortic valvuloplasty }\end{array}$ \\
\hline 2013 & $\begin{array}{c}\text { Alidjinou } \\
\text { Médicine et Maladies } \\
\text { Infectieuses [28] }\end{array}$ & $\begin{array}{l}\text { 61-year-old male with sigmoid colon } \\
\text { cancer with urethral stenting for } \\
\text { tumor-related hydronephrosis } \\
\text { developed G. vaginalis bacteremia. }\end{array}$ & Blood & G. vaginalis & $\begin{array}{l}\text { Amikacin, ceftriaxone }+ \text { metronidazole } \\
\text { (10 days })\end{array}$ \\
\hline 2015 & $\begin{array}{l}\text { Babics } \\
\text { Médicine et Maladies } \\
\text { Infectieuses [31] }\end{array}$ & $\begin{array}{l}\text { 36-year-old male with history of } \\
\text { recurrent UTIs developed G. vaginalis } \\
\text { bacteremia. }\end{array}$ & Blood, Urine & G. vaginalis & $\begin{array}{l}\text { Azithromycin } \\
\text { (14 days) }\end{array}$ \\
\hline 2017 & $\begin{array}{l}\text { Pritchard } \\
\text { Infectious Diseases in } \\
\text { Clinical Practice [34] }\end{array}$ & $\begin{array}{l}\text { 36-year old male with nephrolithiasis } \\
\text { developed pyelonephritis and } G \text {. } \\
\text { vaginalis bacteremia. }\end{array}$ & Blood, Urine & G. vaginalis & $\begin{array}{l}\text { Metronidazole } \\
\quad(14 \text { days })\end{array}$ \\
\hline
\end{tabular}

Abbreviations: BID: twice a day; TID: three times a day; QID: four times a day; TMP-SMX: trimethoprim-sulfamethoxazole; UTI: urinary tract infection; TURP: transurethral prostatectomy; $\mathrm{n} / \mathrm{a}=$ not available; $\mathrm{sp} .:$ species 


\subsection{Prevotella bivia}

Prevotella spp. are part of the cervical flora and are known to cause pelvic inflammatory disease along with perirectal abscesses [36,37]. In up to $40 \%$ of healthy women and in a higher proportion of those with BV, Prevotella DNA has been detected in vaginal epithelia [38]. They are Gram-negative anaerobic rods that are related to Bacteroides spp.; however, they are not able to grow in the presence of bile and are unable to hydrolyze esculin. They are usually susceptible to clindamycin, metronidazole, imipenem, and amoxicillin/clavulanate [39]. The presence of Prevotella in men has also been related by some to BV in their sexual partners [40]. P. bivia infection has been reported to cause penile abscesses in concomitant infection with Streptococcus constellatus, in which case treatment involved surgical drainage and antibiotic treatment initially with IV vancomycin and clindamycin, and then oral amoxicillin/clavulanate [41].

A commensal relationship between G. vaginalis and P. bivia has been proposed, with ammonia flow as the mechanism to support the hypothesis. In a study by Pybus et al., strains of P. bivia and G. vaginalis were studied for nutrient substrate utilization. Ammonia produced by P. bivia stimulated G. vaginalis growth, and amino acids produced by G. vaginalis enhanced P. bivia growth [42]. One prospective study investigating the induction of incident $B V$ via daily vaginal specimen collection showed P. bivia had a higher mean relative abundance among cases prior to incident $\mathrm{BV}$, suggesting a synergy between P. bivia and G. vaginalis prior to a BV infection [43].

\section{Case Discussion}

Our patient developed a unilateral scrotal abscess caused by G. vaginalis and P. bivia. A scrotal abscess may result from the extension of epididymo-orchitis, rupture of testicular abscess, spread of intra-abdominal infection such as appendicitis via patent process vaginalis, a pathological urethro-ejaculatory duct reflux, a hematogenous spread of a systemic infection, or idiopathic process [44]. More superficially, scrotal abscess can result from the spread of cellulitis or an infected hair follicle.

Our patient became colonized with G. vaginalis after acquiring it sexually from one, or both, of his female partners, and was likely harboring it in a seminal or prostatic reservoir. He then developed a scrotal abscess, likely as a result of a minor skin trauma (such as shaving or scratching), causing a skin and soft tissue infection, that spread to the scrotum, or a subclinical urethritis/epididymo-orchitis that extended to the scrotum.

The treatment of $G$. vaginalis in symptomatic women with BV has been established with metronidazole or clindamycin. However, treatment of this infection has not been well studied in men. Since the patient had clinical improvement with IV ceftriaxone, we opted to continue with a beta-lactam upon discharge and add metronidazole for 14 days.

\section{Conclusions}

We present a case of an adult male with morbid obesity who developed a unilateral scrotal abscess caused by G. vaginalis and P. bivia. In a review of literature, including several other reported cases of G. vaginalis, this case appears to be the first case report of such a clinical presentation. This case also demonstrates that $G$. vaginalis with the symbiotic infection of $P$. bivia may be an occasional cause of genitourinary abscess formation in both males and females, and its growth should not be neglected. Given the sexual transmission of G. vaginalis, the growth of this bacteria in a male should be considered as a pathogen in males presenting with clinical urogenital disease and as a reservoir for recurrent bacterial vaginosis in his female partner.

Author Contributions: Writing—original draft preparation: A.B., F.D.; Writing-review and editing: A.B., C.N.; Supervision: C.N. All authors have read and agreed to the published version of the manuscript.

Funding: This manuscript received no external funding.

Conflicts of Interest: The authors declare no conflict of interest. 


\section{References}

1. Allsworth, J.E.; Peipert, J.F. Prevalence of bacterial vaginosis: 2001-2004 National Health and Nutrition Examination Survey data. Obstet. Gynecol. 2007, 109, 114-120. [CrossRef] [PubMed]

2. Muzny, C.A.; Łaniewski, P.; Schwebke, J.R.; Herbst-Kralovetz, M.M. Host-vaginal microbiota interactions in the pathogenesis of bacterial vaginosis. Curr. Opin. Infect. Dis. 2020, 33, 59-65. [CrossRef] [PubMed]

3. Florez, C.; Muchada, M. Bacteremia due to Gardnerella vaginalis: Report of two cases. Clin. Infect. Dis. 1994, 18, 125. [CrossRef]

4. Agostini, A.; Beerli, M. Gardnerella vaginalis bacteremia after vaginal myomectomy. Eur. J. Obstet. Gynecol. Biol. 2003, 108, 229. [CrossRef]

5. Reminer, L.; Reller, B. Gardnerella vaginalis bacteremia: A review of thirty cases. Obstet. Gynecol. 1984, 64, 70-172.

6. Leopold, S. Heretofore undescribed organism isolated from the genitourinary system. U.S. Armed Forces Med. J. 1953, 4, 263-266.

7. Gardner, H.L.; Dukes, C.D. Haemophilus vaginalis vaginitis. A newly defined specific infection previously classified as "nonspecific vaginitis". Am. J. Obster. Gynecol. 1955, 69, 692-976. [CrossRef]

8. Piot, P.; Van Dyck, E.; Peeters, M.; Hale, J.; Totten, P.A.; Holmes, K.K. Biotypes of Gardnerella vaginalis. J. Clin. Microbiol. 1984, 20, 677-679. [CrossRef]

9. Dawson, S.; Ison, C.; Csonka, G.; Easmon, C. Male carriage of Gardnerella vaginalis. Br. J. Vener. Dis. 1982, 58, 243-245. [CrossRef]

10. Holst, E.; Mårdh, P.; Thelin, I. Recovery of anaerobic curved rods and Gardnerella vaginalis from the urethra of men, including male heterosexual consorts of female carriers. Scand. J. Urol. Nephrol. Suppl. 1984, 86, 173-177.

11. Kinghorn, G.; Jones, B.; Chowdhury, F.; Geary, I. Balanoposthitis associated with Gardnerella vaginalis infection in men. Br. J. Vener. Dis. 1982, 58, 127-129. [CrossRef] [PubMed]

12. Elsner, P.A.; Hartmann, A. Gardnerella vaginalis in the Male Upper Genital Tract: A Possible Source of Reinfection of the Female Partner. Sex. Transm. Dis. 1987, 14, 122-123. [CrossRef] [PubMed]

13. Lam, M.H.; Birch, D.F.; Fairley, K.F. Prevalence of Gardnerella vaginalis in the urinary tract. J. Clin. Microbiol. 1988, 26, 1130-1133. [CrossRef] [PubMed]

14. Hillier, S.L.; Rabe, L.K.; Muller, C.H.; Zarutskie, P.B.; Kuzan, F.A.; Stenchever, M. Relationship of Bacteriologic Characteristics to Semen Indices in Men Attending an Infertility Clinic. Obstet. Gynecol. 1990, 75, 800-804. [PubMed]

15. Kjærgaard, N.; Kristensen, B.; Hansen, E.S.; Farholt, S.; Schøonheyder, H.; Uldbjerg, N.; Madsen, H. Microbiology of semen specimens from males attending a fertility clinic. APMIS 1997, 105, 566-570. [CrossRef] [PubMed]

16. Ison, C.; Easmon, C. Carriage of Gardnerella vaginalis and anaerobes in semen. Genitourin. Med. 1985, 61, 120-122. [CrossRef] [PubMed]

17. Holst, E. Reservoir of four organisms associated with bacterial vaginosis suggests lack of sexual transmission. J. Clin. Microbiol. 1990, 28, 2035-2209. [CrossRef]

18. Schwebke, J.R.; Rivers, C.; Lee, J. Prevalence of Gardnerella vaginalis in Male Sexual Partners of Women With and Without Bacterial Vaginosis. Sex. Transm. Dis. 2009, 36, 92-94. [CrossRef]

19. Verstraelen, H.; Verhelst, R.; Vaneechoutte, M.; Temmerman, M. The epidemiology of bacterial vaginosis in relation to sexual behaviour. BMC Infect. Dis. 2010, 10, 81. [CrossRef]

20. Burdge, D.R.; Bowie, W.R.; Chow, A.W. Gardnerella vaginalis-associated balanoposthitis. Sex. Transm. Dis. 1986, 13, 159-162. [CrossRef]

21. Bastida, V.M.; López, O.P.; Rovira, L.J.; Martinez, M.J.; Expósito, A.M. Garderella vaginalis bacteremia in an adult male. Eur. J. Clin. Microbiol. Infect. Dis. Publ. Eur. Soc. Clin. Microbiol. 1997, 16, 400-401. [CrossRef] [PubMed]

22. Calvert, L.D.; Collins, M.; Bateman, J.R.M. Multiple abscesses caused by Gardnerella vaginalis in an immunocompetent man. J. Infect. 2005, 51, E27-E29. [CrossRef] [PubMed]

23. Legrand, J.C.; Alewaeters, A.; Leenaerts, L.; Gilbert, P.; Labbe, M.; Glupczynski, Y. Gardnerella vaginalis bacteremia from pulmonary abscess in a male alcohol abuser. J. Clin. Microbiol. 1989, 27, 1132-1134. [CrossRef] [PubMed] 
24. Wilson, J.; Barratt, A. An unusual case of Gardnerella vaginalis septicaemia. Br. Med. J. (Clin. Res. Ed.) 1986, 293, 309. [CrossRef]

25. Denoyel, G.A.; Drouet, E.B.; De Montclos, H.P.; Schanen, A.; Michel, S. Gardnerella vaginalis Bacteremia in a Man with Prostatic Adenoma. J. Infect. Dis. 1990, 161, 367-368. [CrossRef]

26. Finkelhor, R.S.; Wolinsky, E.; Kim, C.H.; Tchou, P.; Frengley, J.D. Gardnerella vaginalis perinephric abscess in a transplanted kidney. N. Engl. J. Med. 1981, 304, 846.

27. Patrick, S.; Garnett, P.A. Corynebacterium vaginale bacteraemia in a man. Lancet 1978, 1,987-988. [CrossRef]

28. Alidjinou, E.; Bonnet, I.; Canis, F.; Dewulf, G.; Mazars, E.; Cattoen, C. Bactériémie à Gardnerella vaginalis chez un homme. Médecine et Maladies Infectieuses 2013, 43, 434-437. [CrossRef]

29. Harper, E.; Jones, A. Comparison of radiometric and gas capture systems for blood cultures. J. Clin. Pathol. 1987, 40, 243. [CrossRef]

30. Sturm, A.W. Gardnerella vaginalis in infections of the urinary tract. J. Infect. 1989, 18, 45-49. [CrossRef]

31. Babics, A.; Roussellier, P. Gardnerella vaginalis: An Overlooked pathogen in male patients? Med. Mal. Infect. 2015, 10, 423-424. [CrossRef] [PubMed]

32. Abercrombie, G.; Allen, J.; Maskell, R. Cornyebacterium vaginale urinary-tract infection in a man. Lancet 1978, 1, 766. [CrossRef]

33. Lagacé-Wiens, P.R.; Ng, B.; Reimer, A.; Burdz, T.; Wiebe, D.; Bernard, K. Gardnerella vaginalis Bacteremia in a Previously Healthy Man: Case Report and Characterization of the Isolate. J. Clin. Microbiol. 2008, 46, 804-806. [CrossRef] [PubMed]

34. Pritchard, H. A Case of Pyelonephritis with Bacteremia Caused by Gardnerella vaginalis in a Man. Infect. Dis. Clin. Pract. 2018, 26, e61-e63. [CrossRef]

35. Yoon, H.; Chun, J.; Kim, J.; Kang, S.; Na, D. Gardnerella vaginalis septicaemia with pyelonephritis, infective endocarditis and septic emboli in the kidney and brain of an adult male. Int. J. STD AIDS. 2010, 21, 653-657. [CrossRef] [PubMed]

36. Brook, I.; Frazier, E.H. The aerobic and anaerobic bacteriology of perirectal abscesses. J. Clin. Microbiol. 1997, 35, 2974-2976. [CrossRef]

37. Gossling, J. Occurrence and pathogenicity of the Stretococcus milleri group. Rev. Infect. Dis. 1988, 10, 257-285. [CrossRef]

38. Srinivasan, S.; Fredricks, D.N. The Human Vaginal Bacterial Biota and Bacterial Vaginosis. Interdiscip. Perspect. Infect. Dis. 2008, 2008, 750479. [CrossRef]

39. Brook, I. Microbiology and management of polymicrobial femal genital tract infections inadolescents. J. Pediatr. Adolesc. Gynecol. 2002, 15, 217-226. [CrossRef]

40. Price, L.; Liu, C.; Johnson, K.; Aziz, M.; Lau, M.; Bowers, J.; Ravel, J.; Keim, P.; Serwadda, D.; Wawer, M.; et al. The Effects of Circumcision on the Penis Microbiome (Penis Microbiome: Circumcision). PLoS ONE 2010, 5 , E8422. [CrossRef]

41. Nalmas, S.; Bishburg, E.; Chan, T.; Abter, E.I. Streptoccus constellatus and P. bivia penile abscess. Sci. World J. TSW Urol. 2007, 7, 1631-1633. [CrossRef] [PubMed]

42. Pybus, V.; Onderdonk, A.B. Evidence for a commensal, symbiotic relationship between Gardnerella vaginalis and Prevolla bivia involving ammonia: Potential significance for bacterial vaginosis. J. Infect. Dis. 1997, 175, 406-413. [CrossRef] [PubMed]

43. Muzny, C.; Blanchard, E.; Taylor, C.; Aaron, K.; Talluri, R.; Griswold, M.; Redden, D.; Luo, M.; Welsh, D.; Van Der Pol, W.J.; et al. Identification of Key Bacteria Involved in the Induction of Incident Bacterial Vaginosis: A Prospective Study. J. Infect. Dis. 2018, 218, 966-978. [CrossRef] [PubMed]

44. Ramareddy, R.S.; Alladi, A. Scrotal abscess: Varied etiology, associations, and management. J. Indian Assoc. Pediatr. Surg. 2016, 21, 164-168. [PubMed]

(C) 2020 by the authors. Licensee MDPI, Basel, Switzerland. This article is an open access article distributed under the terms and conditions of the Creative Commons Attribution (CC BY) license (http://creativecommons.org/licenses/by/4.0/). 